\title{
SALEZJANIE POLSCY - KAPELANI WOJSKOWI I DUSZPASTERZE NA OBCZYŹNIE
}

\section{WPROWADZENIE}

Salezjanie realizowali swoje posłannictwo młodzieżowe głównie poprzez prowadzenie różnego typu szkół dla chłopców, domów dziecka oraz oratoriów (rodzaj świetlic środowiskowych przy parafiach i domach dydaktyczno-wychowawczych). Z różnych jednak przyczyn nie podejmowali się prowadzenia duszpasterstwa polowego i wojskowego ${ }^{1}$. Na to składało się kilka przyczyn, wśród których należy wymienić: brak wolnego personelu czy życie poza wspólnotą zakonną (nieprzestrzeganie obserwancji). Wśród salezjanów zdarzały się wyjątki, że niektórzy księża podczas pierwszej wojny światowej spieszyli z posługą sakramentalną żołnierzom polskim znajdującym się w obozach jenieckich, na froncie czy przebywającym w szpitalach. Od początku formowania się wojska polskiego

Ks. prof. dr hab. JAN PIETRZYKowsKI SDB - Instytut Historii Uniwersytetu Kardynała Stefana Wyszyńskiego w Warszawie, dyrektor Archiwum Salezjańskiego Inspektorii Warszawskiej; e-mail: j.pietrzykowski@uksw.edu.pl. ORCID: https://orcid.pl/0000-0001-5414-3902.

${ }^{1}$ Do wyjątków należy zaliczyć salezjanów z Łodzi przy ul. Wodnej, którzy początkowo, od roku 1950 na prośbę Kurii Biskupiej łódzkiej pomagali w obsłudze kościoła garnizonowego pw. św. Jerzego. Pierwszym stałym duszpasterzem od 1963 r., a następnie proboszczem parafii wojskowej (1969-1981) był ks. Franciszek Kamiński. W 1971 r. ks. inspektor Feliks Żołnowski na prośbę Generalnego Dziekana Wojska Polskiego, ks. dr. Juliana Humeńskiego, oddelegował do duszpasterstwa wojskowego jeszcze trzech księży: Januarego Chorążewicza, Mariana Kuberę i Henryka Pietrewicza (1971). Wyżej wymienieni księża po przejściu na emeryturę nie wrócili do życia wspólnotowego w Towarzystwie Salezjańskim, a trzech z nich zostało inkardynowanych do różnych diecezji w Polsce. Por. Archiwum Salezjańskie Inspektorii Warszawskiej [dalej: ASIW], t. Byłe Placówki, Łódź św. Jerzy, Umowa o pracę zawarta między Proboszczem Garnizonu Łódź 2 a ks. H. Pietrewiczem, Łódź 12 IV 1971; Protokół z wizytacji kanonicznej przeprowadzonej przez ks. S. Rokitę, Łódź 16 I 1976; Wykaz Placówek i Współbraci Polskich Prowincji Towarzystwa Salezjańskiego 1978-1989, Kraków-Lódź (mała poligrafia); F. KAMiśski, Moja droga do kapłaństwa, Warszawa 2004, s. 43. 
i jego działalności poza krajem, nieliczni salezjanie podejmowali obowiązki kapelanów z inicjatywy prywatnej i nie miało to charakteru akcji zorganizowanej. Formalnie nie zostali oni oddelegowani do tej pracy, a funkcje dobroczynne wykonywali jako dodatkowe, sezonowe zajęcia. Przełożeni tylko w sposób milczący (pozwolenie domyślne) aprobowali tę formę posłannictwa kapłańskiego. Na progu niepodległości Polski władze Towarzystwa Salezjańskiego zdecydowanie nie popierały angażowania się księży w duszpasterstwo polowe. W Archiwum Centralnym Towarzystwa Salezjańskiego w Rzymie zachowały się ślady korespondencji z 1918 r. pomiędzy Polskim Komitetem Narodowym a Domem Generalnym w Turynie. Władze wojskowe listownie zwracały się z prośbą do przełożonych zakonnych o oddelegowanie kilku księży dla organizujących się Polskich Sił Zbrojnych we Francji. Z nieznanych bliżej przyczyn odpowiedzi były wymijające i negatywne ${ }^{2}$.

Do salezjanów pionierów, którzy posługiwali żołnierzom polskim na obczyźnie, należał ks. Jan Symior (1879-1959)³. Przeznaczony do duszpasterstwa polonijnego w Anglii, od września 1913 r. kierował jako rektor Polską Misją Katolicką przy Mercer Street w Londynie. Dodatkowo w latach 1916-1919 otaczał opieką duszpasterską Polaków i Ukraińców w obozach jenieckich na terenie Wielkiej Brytanii oraz Polaków w mundurach armii kanadyjskiej. Ponadto współpracował z powołanym w 1917 r. w Lozannie Komitetem Narodowym Polskim . Podobnie też

2 Archivio Salesiano Centrale [dalej: ASC], E 999 Polonia Generica, Comitato Nazionale Polacco do ks. Generała P. Albery, Roma 30 XI 1918, 23 XII 1918, 20 I 1919.

${ }^{3}$ Urodził się 12 XII w Kadłubie Wielkim na Śląsku Opolskim w rodzinie Antoniego, rolnika, i Józefy z domu Niesłony. Miał sześcioro rodzeństwa, w tym dwóch księży salezjanów: Franciszka (1874) i Antoniego (1882-1939). W 1894 r. podjął naukę w gimnazjum salezjańskim dla Polaków w Valsalice koło Turynu. Na zakończenie nowicjatu 3 X 1898 złożył śluby zakonne w Foglizzo. Filozofię studiował w Ivrei i w Turynie, a teologię w Marsylii i prywatnie w Oświęcimiu. 22 IV 1905 w Krakowie przyjął święcenia kapłańskie. Pracował w domach salezjańskich w Oświęcimiu (19051907), Przemyślu (1907-1913), Londynie (1913-1921), Aleksandrowie Kujawskim (1921-1925), Krakowie (1925-1938), gdzie był dyrektorem domu zakonnego, proboszczem parafii św. Stanisława Kostki i budowniczym kościoła, w Oświęcimiu (1938-1939), we Lwowie na Łyczakowie (19391942). W latach 1942-1959 był kapelanem sióstr albertynek w Rząsce koło Krakowa. Tam zmarł 14 XII i został pochowany na cmentarzu Rakowickim w Krakowie. Por. Archiwum Salezjańskie Inspektorii Krakowskiej [dalej: ASIK], t. Personalna ks. J. Symiora; J. PIETRZYKowski, Symior Jan (1879-1959), salezjanin, rektor Polskiej Misji Katolickiej w Londynie, w: Polski Stownik Biograficzny, red. B. Swolkień, J. Syska, t. 46, z. 189, Warszawa 2009, s. 239.

${ }^{4}$ Por. Polska Misja Katolicka w Londynie 1894-1944. Księga pamiatkowa, Londyn [1951], s. 20-22, 50-51; J. Pietrzykowski, Un secolo di presenza di salesiani Polacchi fra gli emigranti. Cenni storici, „Ricerche Storiche Salesiane” 1991, nr 1(34), s. 152; R. SzczYGIELSKI, Działalność salezjanów polskich na rzecz emigracji londyńskiej 1894-1967, Lublin 2001, mps, s. 41-42 (Biblioteka WSD w Lądzie nad Wartą). 
w obozach jenieckich na terenie Włoch służbę duszpasterską pełnili polscy księża, m.in. salezjanie z Turynu'

Do wyjątków należał ks. dr Ignacy Dobiasz ${ }^{6}$, który od 1916 r. był wykładowcą filozofii i teologii w domach formacyjnych w Foglizzo, a następnie w Cavagliá koło Turynu. W 1919 r. zgłosił się na kapelana formujących się polskich oddziałów wojskowych w Piemoncie. Razem z żołnierzami wyjechał do Francji i z armią gen. Józefa Hallera przeszedł cały szlak bojowy. Następnie od roku 1920 był profesorem w Salezjańskim Studentacie Filozoficznym w Krakowie. Przez kolejny rok był ponownie kapelanem hallerczyków. Z wojska powrócił z Krzyżem Walecznych ${ }^{7}$.

\section{WŚRÓD SWOICH NA WĘGRZECH}

Sytuacja życiowa salezjanów, w jakiej znaleźli się podczas drugiej wojny światowej, przyczyniła się do angażowania się księży w duszpasterstwo polowe i pracę duszpasterską wśród rodaków na obczyźnie. Trzech księży z Inspektorii św. Jacka z siedzibą w Krakowie (krakowskiej, południowej) podczas okupacji przebywało na Węgrzech, gdzie zaangażowali się do opieki duchowej nad rodakami. Nominację na kapelana miał tylko ks. Alojzy Golubski (1894-1984), który pod koniec

${ }^{5}$ Por. S. NABYwanIEC, Poshuga duszpasterska na frontach I wojny światowej, „Resovia Sacra” 23(2016), s. 221-222.

${ }^{6}$ Urodził się 14 VII 1890 w miejscowości Więcławice k. Włocławka z rodziców Jakuba i Jadwigi z d. Velerius. W latach 1901-1905 uczył się w salezjańskim gimnazjum w Oświęcimiu. Na zakończenie nowicjatu w Daszawie k. Stryja 29 IX 1906 złożył śluby zakonne. Praktykę pedagogiczno-pastoralną zaliczył w Ljubljanie i w Radnej (Słowenia). W latach 1912-1916 studiował filozofię i teologię na Papieskim Uniwersytecie Gregoriańskim w Rzymie i z tych dyscyplin uzyskał doktoraty. 23 IV w Rzymie otrzymał święcenia kapłańskie. Po powrocie z wojska pracował w Krakowie i Oświęcimiu. Był dyrektorem domów i gimnazjów w Aleksandrowie Kujawskim (1926-1931), Różanymstoku (1931-1934). Od 1934 r. pełnił obowiązki dyrektora i rektora Salezjańskiego Instytutu Teologicznego w Krakowie, wykładowcy teologii i radcy inspektorialnego. Aresztowany przez Niemców 23 V 1941, zmarł 21 VII 1941 w Auschwitz. Od 2003 r. toczy się jego proces beatyfikacyjny. Por. ASIK, t. Personalna ks. I. Antonowicza, karta osobowa; J. PIETRZYKowski, Zastużeni dla Aleksandrowa Kujawskiego, w: Salezjanie w Aleksandrowie Kujawskim 1919-2009. Studia i materiały źródtowe, red. J. Wąsowicz, Piła 2009, s. 96-98; B. KANT, Księga męczeństwa salezjanów polskich, Warszawa 2012, s. 271-274.

7 Por. Nekrolog salezjanów polskich 1891-1976, Kraków-Lódź 1976, mps, s. 239; A. CieCHALski, B. ZıóŁкowski, Antonowicz Ignacy Tadeusz (SDB) (1980-1941), salezjanin, kapelan Armii Polskiej gen. J. Hallera, profesor teologii, dyr. salezjańskich zakładów naukowych, męczennik z Auschwitz, kandydat na oltarze, w: Kazimierz Wielki oraz niepospolici z Kowala i okolic. Stownik biograficzny. Kalendarium, red. Z.J. Zasada, B. Ziółkowski, Włocławek-Kowal 2006, s. 36-37. 
sierpnia 1939 r. został zmobilizowany w Ostrzeszowie do stawienia się w Lublinie ${ }^{8}$. Ksiądz inspektor Adam Cieślar sankcjonował to listem posłuszeństwa i przeznaczył ks. Golubskiego do Tudorowa na Wołyniu, aby tam zorganizował opiekę duszpasterską nad młodzieżą i pogranicznymi oddziałami wojska polskiego. Niestety, z powodu trudności komunikacyjnych kapelan nie mógł dołączyć do swojego pułku. Dopiero 16 września dotarł do Równego na Wołyniu. Po wyrobieniu przepustki, w cywilnym ubraniu 12 października wyjechał pociągiem do Lwowa. Tam otrzymał przydział do placówki duszpasterskiej w Worochcie (dekanat stanisławowski), nad granicą węgierską. 26 grudnia 1939 r. zostawił na plebanii list do księdza dziekana i w towarzystwie dwóch oficerów polskich przekroczył przedwojenną granicę polsko-węgierską ${ }^{9}$. Po zarejestrowaniu się w punkcie zbornym, zgłosił się do konsulatu polskiego w Budapeszcie i 29 grudnia oddał się do dyspozycji bp. Karola Radońskiego. Z węgierskiej Kurii Polowej ks. Golubski otrzymał jurysdykcję do sprawowania duszpasterstwa w obozach dla Polaków. Początkowo, do Wielkanocy 1940 r., pracował w obozie dla internowanych około 300 żołnierzy w Csaroda koło Beregszasz. Następnie od czerwca do września 1940 r. przebywał wśród internowanych około 100 oficerów w Lengyeltóti blisko Balatonu. $\mathrm{Na}$ własną prośbę został przeniesiony do analogicznej placówki w miejscowości Eger, gdzie pracował od września 1940 do kwietnia 1943 r. Kapelan mieszkał gościnnie u franciszkanów ${ }^{10}$. Kolejnym miejscem posługiwania ks. Golubskiego był Magyaróvár nad granicą austriacką, gdzie kilkudziesięciu polskich szeregowców i podoficerów pracowało w hucie aluminium. W połowie lipca 1944 r. przeniósł się do domu salezjańskiego w Szombathery, gdzie doczekał końca drugiej wojny świa-

${ }^{8}$ Urodził się 16 III we Wlewsku (pow. brodnicki), w rodzinie Walentego i Marianny z d. Szczebrowskiej. W Radnej (Słowenia) odbył nowicjat, ale pierwsze śluby zakonne złożył 1 VII 1915 w Oświęcimiu. Wcielony do wojska niemieckiego, przez kilka miesięcy przebywał na froncie francuskim. Filozofię studiował w Radnej, a teologię w Foglizzo; 27 VII 1923 w Krakowie przyjął święcenia kapłańskie. Był socjuszem magistra nowicjatu w Kleczy Dolnej i w Czerwińsku nad Wisłą. W 1927 r. został dyrektorem sierocińca w Ciechanowie, następnie był dyrektorem w Wilnie (1929-1932). Ponadto pracował w Warszawie, następnie był dyrektorem w Kielcach (1936-1938) i w Lublinie (19361938). Po powrocie z Węgier pełnił obowiązki administratora w Marszałkach (1945-1946), kapelana sióstr salezjanek w Lubini Wielkiej (1946-1950), administratora parafii Kretków (1950-1956). Przez rok 1956/1957 przebywał na kuracji w Poznaniu. W latach 1957-1975 pracował na terenie diecezji warmińskiej i był tam kolejno proboszczem par. Łukta, Jonkowo, Świątki. Od 1975 r. w charakterze rezydenta przebywał w par. Kobyla. Zmarł 5 XI 1984 w Rydułtowach i został pochowany w Ostrzeszowie. Por. ASIK, t. Personalna ks. A. Golubskiego, Karta osobowa.

9 Por. A. Golubski, Jeśli chcesz żyć - idź na Węgry, w: Historia prowincji św. Jacka Towarzystwa Salezjańskiego w Polsce, red. J. Ślósarczyk, t. IV, Pogrzebień 1966, mps, s. 187-209.

${ }^{10}$ ASIK, t. Personalna ks. A. Golubskiego, ks. A. Golubski do ks. A. Cieślara, Eger 12 XII 1940, 2 IV 1941; A. GoluBsKi, Na Węrzech, w: Historia prowincji, t. IV, s. 218-223. 
towej. Do końca pobytu na Węgrzech pobierał żołd kapelana. W sierpniu $1945 \mathrm{r}$. specjalnym pociągiem wrócił do Polski ${ }^{11}$.

1 września 1939 r. na ogólny rozkaz ewakuacji miasta salezjanie opuścili Ostrzeszów, gdzie prowadzili gimnazjum, liceum, internat i oratorium. Wśród personelu znajdował się ks. Leon Czerwiński (1894-1969)12, który po wędrówce na południowo-wschodnie tereny II Rzeczypospolitej nielegalnie przekroczył granicę polsko-węgierską. Początkowo mieszkał u salezjanów w Balassagyarmat. Tam został aresztowany przez policję węgierską i od lipca do października 1940 r. przebywał w obozie karnym. Po opuszczeniu miejsca odosobnienia ks. Czerwiński podjąı obowiązki kapelana w pięciu obozach dla internowanych Polaków wojskowych ${ }^{13}$.

Psychozie wrześniowej ucieczki przed Niemcami na wschód ulegli też salezjanie z Kielc. Należący do tego domu zakonnego ks. Erazm Malczyk (1897-1977) ${ }^{14}$, razem z bratem i jego żoną, 19 września 1939 r. przekroczył granicę i zamieszkał w obozie w Gyula, a następnie w Budapeszcie. Tam wśród rodaków pełnił posługę duszpasterską i dodatkowo był nauczycielem religii w polskim gimnazjum i liceum na terenie obozu w Balatonboglarze. Od 1941 r. ks. Malczyk przebywał w obozie polskim w Hevizszentandras, skąd w niedziele motocyklem dojeżdżał do podobnych

11 Tamże, s. 336-339.

12 Urodził się 24 VI w Zagrodach (pow. olkuski), w rodzinie Jana i Agaty z d. Palimąka. Nowicjat odbył w Radnej i na jego zakończenie 10 VI 1916 r. złożył śluby zakonne. Filozofię studiował w Radnej i w Oświęcimiu, a praktykę pedagogiczno-pastoralną zaliczył w Oświęcimiu i w Krakowie. Teologię studiował w Turynie i tam 13 VII 1925 r. otrzymał święcenia kapłańskie. Po powrocie do Polski pracował w Kleczy Dolnej, Krakowie, Różanymstoku i Ostrzeszowie. Dodatkowo na Uniwersytecie Poznańskim studiował filologię polską i z tej dyscypliny w 1929 r. uzyskał tytuł magistra, a w 1932 dyplom nauczyciela szkół średnich. W 1945 r. wrócił do Ostrzeszowa i podjął przedwojenne obowiązki dyrektora i nauczyciela. Po zlikwidowaniu tej placówki przez władze partyjno-państwowe ks. Czerwiński zaangażował się w duszpasterstwo rekolekcyjne i parafialne: w Kielcach, Szczyrku, Lubinie Legnickim, Kuźnicy Cieszyckiej i w Kopcu, gdzie 17 IV 1969 r. zmarł i został pochowany na cmentarzu parafialnym w Białej. Por. ASIK, t. Personalna ks. L. Czerwińskiego, Karta osobowa.

13 ASIK, sygn. 1546, ks. A. Cieślar, Kronika 1940, 14 X 1940; ks. L. Czerwiński do ks. A. Baraniaka, Balassagyarmat, 4 IV 1940, w: Acta Hlondiana. Materiały do życia i działalności kardynała Augusta Hlonda, prymasa Polski 1881-1948, zebrał S. Kosiński, t. 4, cz. 10, Ląd 1971, mps, s. 72.

14 Urodził się 21 V 1897 r. w Rywałdzie Średnim z rodziców Franciszka i Franciszki z d. Podgórczyk. Do gimnazjum uczęszczał w Wadowicach i w Krakowie. 15 VIII 1927 r. w Czerwińsku na zakończenie nowicjatu złożył pierwszą profesję zakonną. Praktykę pedagogiczno-duszpasterską zaliczył w Dworcu na terenie województwa nowogrodzkiego. Studia seminaryjne odbył w Krakowie i tam 15 VI 1935 r. przyjął święcenia kapłańskie. Pracował jako administrator i kierownik szkoły w Ostrzeszowie 1935/1936 i w Kielcach 1936-1939. W 1949 r. udał się do Stanów Zjednoczonych, gdzie po kilku latach opuścił Towarzystwo Salezjańskie. Pod koniec życia został sparaliżowany i wrócił do Polski. 11 XII 1977 r. zmarł u siostry w Woli Duchackiej koło Krakowa. Por. ASIK. T. Personalna ks. E. Malczyka, karta osobowa. 
ośrodków w Zalaszánto i Karmacs. Po zakończeniu II wojny światowej za zgodą ks. inspektora Jana Ślósarczyka pozostał wśród Polaków i do roku 1949 był rektorem (kapelanem) kościoła w Kabanyi. Ponadto prymas Węgier kard. Jozsef Mindszenty powierzył mu obowiązki duszpasterza Kolonii Polskiej w Budapeszcie ${ }^{15}$.

\section{BYLI ZESŁAŃCY SOWIECCY W II KORPUSIE}

Wśród księży salezjanów - kapelanów wojskowych na obczyźnie znaczną grupę tworzyli zesłańcy syberyjscy: Józef Czerniecki, Antoni Guzik z inspektorii krakowskiej oraz Franciszek Tomasik i Jan Kapusta z inspektorii warszawskiej. Dla nich zaangażowanie się $\mathrm{w}$ duszpasterstwo $\mathrm{w}$ organizowanej armii polskiej na terytorium Związku Radzieckiego było szansą na wydostanie się z „nieludzkiej ziemi”. Najmniej szczęścia spośród nich miał ks. Jan Kapusta ${ }^{16}$, który po amnestii zgłosił się do formującej się armii polskiej w Buzuluku i został przeznaczony do polskich przesiedleńców w Kazachstanie (Aktiubińska obłast). Pracował tam od 17 listopada 1941 do 10 maja 1942 r. Następnie był kapelanem junaczek w Karszy w Uzbekistanie. 15 sierpnia 1942 r. na granicy, podczas ewakuacji II Korpusu do Persji, został ponownie aresztowany przez władze sowieckie pod zarzutem szpiegostwa. Przez 17 miesięcy siedział w więzieniach moskiewskich na Łubiance i Butyrkach. Został zaocznie skazany na 10 lat łagru w Workucie. Do kraju wrócił dopiero 30 grudnia 1955 r. Zmarł 5 lutego 1964 r. w Lądzie i został pochowany na cmentarzu parafialnym ${ }^{17}$.

${ }_{15}$ ASC, F 000, Salesiani durante l'occupazione, Sprawozdanie z działalności duszpasterskiej od 12 V 1941 do 12 VI 1942, Duanok, 12 VI 1942, mps, s. 1-4; ASIK, t. Personalna ks. E. Malczyka, ks. E. Malczyk do ks. A. Cieślara, Rakospalota, listopad 1939, Hevizszentandras, 1 II 1941; ks. E. Malczyk do ks. J. Ślósarczyka, Budapeszt, 17 IX 1948; M. OstojA-MitкiEwICZ, ,, Wojna jest grzechem”. Przykłady braterstwa polsko-węierskiego w okresie II wojny światowej, Warszawa 2001, s. 61, 217.

16 Jan Kapusta, syn Józefa i Tekli z d. Wesołowskiej, ur. 13 VII 1894 w Witowie, pow. pińczowski. Nowicjat odbył w Pleszowie k. Krakowa i tam 17 VII 1918 złożył pierwsze śluby zakonne. Filozofię studiował w Krakowie, a teologię w Oświęcimiu i w Turynie, gdzie 8 VII 1928 przyjął święcenia kapłańskie. Po powrocie do Polski pracował w Wilnie, Przemyślu, Warszawie, a od 1937 r. był dyrektorem domu i proboszczem w Dworcu. Aresztowany 27 XI 1939, przez 15 miesięcy był więziony w Słominie i w Mińsku, a następnie w obozie pracy w Republice Karelsko-Fińskiej. Por. ASIW, t. Personalna ks. J. Kapusty, karta osobowa; Metryka urodzenia Jana Kapusty wyd. przez Prezydium Gminnej Rady Narodowej w Koszycach z 18 V 1952.

17 Archiwum Katedry Polowej WP w Warszawie [dalej: AKP], Księża pracujący aktywnie wśród rodzin wojskowych [b.d.m.w.]; ASIK, sygn. 1687, t. Wspomnienia, Relacja ks. Henryka Dorębowicza spisana przez ks. W. Kapczuka; W. Żurek, ,Jeńcy na wolności”. Salezjanie na terenach bylego ZSRR po II wojnie światowej, Kraków 1998, s. 309-310; T. KRAHEL, Martyrologium duchowieństwa archidiecezji wileńskiej 1939-1945, Białystok 2017, s. 639-640. 
Inaczej potoczyły się wojenne i tułacze losy ks. Franciszka Tomasika (1899$1961)^{18}$ - organizatora i pierwszego dyrektora domu zakonnego i sierocińca w Supraślu koło Białegostoku. Po zajęciu miejscowości przez wojska sowieckie był kilkakrotnie przesłuchiwany przez władze komunistyczne i poczuł się zagrożony aresztowaniem. Za wiedzą dziekana białostockiego, ks. Aleksandra Chodyko, postanowił przedostać się do Generalnego Gubernatorstwa. 4 kwietnia 1940 r. podczas przeprawy kajakiem przez Bug w okolicach Siemiatycz wpadł w ręce straży granicznej. Przez pół roku był więziony w Białymstoku i w Brześciu n. Bugiem. Został wywieziony nad Morze Białe, gdzie miał spędzić osiem lat. Po amnestii został zwolniony i w październiku $1941 \mathrm{r}$. znalazł się na południu ZSSR w polskiej armii. 10 listopada 1941 r. został kapelanem w 7. Baonie Sanitarnym, a 4 kwietnia 1942 r. z wojskiem polskim przybył do Persji. W Teheranie biskup polowy Józef Gawlina zaproponował mu opiekę nad polskimi sierotami w Isfahanie. Zgodził się chętnie, ponieważ zgodnie $\mathrm{z}$ charyzmatem salezjańskim bardziej odpowiadała mu praca z dziećmi i młodzieżą niż „włóczenie się za wojskiem”. Na polu szkolno-wychowawczym ks. Tomasik pracował owocnie i ofiarnie. W wykazach kapelanów z roku 1943 już nie figuruje. W Isfahanie założył 17 różnych zakładów opiekuńczych i 20 różnych szkół dla 2200 dzieci i młodzieży. Przemęczenie było powodem paraliżu, który zmusił go do ograniczenia działalności. Po ewakuacji Polaków z Persji do Libanu w roku 1945 ks. Tomasik pracował w Zouku Mikael. Nie przyjął propozycji wyjazdu do Wielkiej Brytanii, tylko z „resztą” rodaków pozostał na miejscu ${ }^{19}$.

${ }^{18}$ Urodził się 26 VII w Jawczycach k. Wieliczki z rodziców Jana i Anny z d. Dziuban. Nowicjat odbył w Kleczy Dolnej k. Wadowic i na jego zakończenie 28 VII 1921 złożył trzyletnie śluby zakonne. W latach 1921-1924 w Krakowie uzupełniał wykształcenie średnie i studiował filozofię. Trzyletnią praktykę pedagogiczno-pastoralną zaliczył w Lądzie n. Wartą. W latach 1927-1931 studiował teologię w Papieskim Uniwersytecie Gregoriańskim w Rzymie, a 3 VIII 1930 przyjął święcenia kapłańskie w Krakowie. W latach 1931-1936 pracował w Zakładzie im. ks. Siemca w Warszawie, skąd został przeniesiony do Supraśla. Por. ASIW, t. Personalna ks. F. Tomasika, karta osobowa; „Kurier Białostocki” 17 VIII 1939; R. Dzwonkowski, Leksykon duchowieństwa polskiego represjonowanego w ZSRS 1939-1988, Lublin 2003, s. 597.

${ }^{19} \mathrm{~W} 1950$ r. ze względu na stan zdrowia i za zgodą przełożonych przeniósł się do domu salezjańskiego w Betlejem. Wkrótce zamieszkał w pobliskim klasztorze prawosławnym. Od początku 1950 r. przebywał w Damaszku (Syria). Zmarł 18 III 1961 w szpitalu włoskim i został pochowany w Damaszku. W 1966 r. ciało ekshumowano, przewieziono do Libanu i złożono w katakumbach przygotowanych w ogrodzie obok domu salezjańskiego w El Houssoum. Por. ASIW, t. Personalna ks. F. Tomasika, ks. F. Tomasik do ks. S. Rokity, Zouk Mikael 19 XI 1947; Betlejem 8 VIII 1951; Damaszek 21 III 1953; J. Draus, Oświata i nauka polska na Bliskim Wschodzie 1939-1950, Lublin 1983, s. 68; Isfahan miasto polskich dzieci, red. I. Beaupre-Stankiewicz i [in.], Londyn 1988, s. 114, 119; K. KantaK, Dzieje uchodźstwa polskiego w Libanie 1943-1950, Bejrut 1955, s. 117-118; J. KNOTHE, Niedaleko Damaszku, Warszawa 1961, s. 179-182. 
Ksiądz Józef Czerniecki (1909-1996) ${ }^{20}$ na początku okupacji sowieckiej przebywał w domu salezjańskim we Lwowie na Łyczakowie. Podczas pobytu u rodziców w Annowie k. Sokala w lutym 1940 r. został aresztowany przez NKWD, które w ten sposób okazało troskę o bezpieczeństwo Polaków zagrożonych przez Ukraińców. Na stacji kolejowej Lwówek nie skorzystał z możliwości ucieczki, ponieważ nie chciał opuścić rodaków wiezionych na Syberię. Przebywał w posiołku Jokodym w obwodzie archangielskim. Po tzw. amnestii, dopiero 2 lutego 1942 r. mógł zgłosić się do punktu zbornego w Gonzarze i otrzymał przydział na kapelana V Dywizji. Pełnił także obowiązki kapelana rodzin wojskowych w Margelan. W sierpniu 1942 r. przybył do Isfahanu w Persji i był kapelanem 3 Obozu Rodzinnego i katechetą w kilku szkołach. Od lutego 1943 r. przez rok pracował jako katecheta i kierownik ośrodka dla polskich chłopców w Ousbloorn w Afryce. W kwietniu 1944 r. na polecenie władz kościelnych przybył do Włoch i był kapelanem II Batalionu 4. Brygady Wołyńskiej. Towarzyszył oddziałowi wojskowemu w jego szlaku bojowym, a koniec II wojny zastał go w Bolonii. W 1946 r. razem z II Korpusem został przetransportowany do Wielkiej Brytanii. Był kapelanem w obozach wojskowych i dla junaków w Tilshead, Midleroy, Hursley i Fargo, a od roku 1948 kapelanem dla rodzin polskich w Keevil k. Trowbridge. Po zamknięciu obozu w 1956 r. pozostał w tej miejscowości i prowadził tzw. duszpasterstwo objazdowe w skupiskach Polaków. Przy kościele katolickim (angielskim) zorganizował ośrodek duszpasterski dla rodaków i pracował w nim do 1992 r. Ostatnie lata spędził w domu zakonnym w Lublinie na Kalinowszczyźnie. Zmarł 11 sierpnia 1996 r. w miejscowości rodzinnej w Mirocinie i tam został pochowany ${ }^{21}$.

Podobnie męczeński, patriotyczny i tułaczy szlak przeszedł ks. Antoni Guzik (1892-1966) ${ }^{22}$. Podczas okupacji sowieckiej był dyrektorem domu zakonne-

${ }^{20}$ Urodził się 19 X w Mirocinie k. Przeworska. Jego rodzicami byli Jan i Agnieszka z d. Basiak. Pierwsze śluby złożył 24 VII 1928 w Czerwińsku na zakończenie nowicjatu. Studia seminaryjne odbył w Krakowie i tam 29 V 1938 przyjął święcenia kapłańskie. Pracował we Lwowie na Górnym Łyczakowie jako kierownik oratorium i katecheta w szkole żeńskiej im. Zimorowicza. Por. Elenco Generale della Societá di S. Francesco di Sales 1929-1939, Torino 1928-1939; Rodzina salezjańska w Polsce. Wykaz domów i osób, red. L. Kaliński, Warszawa 1988, s. 96.

${ }^{21}$ ASIK, t. Personalna ks. J. Czernieckiego, Pamiętnik, rkps, s. 5-9; AKP, Depesza Szyfr Tajne, Naczelny Wódz do Biskupa Polowego 28 VII 1942, prośba o mianowanie wymienionych księży (J. Czerniecki, A. Guzik) kapelanami na czas wojny; J. GrzYB, Wspomnienie pośmiertne, Lublin 1998, mps, s. 1-3; R. Dzwonkowski, Leksykon duchowieństwa, s. 181-182.

${ }^{22}$ Urodził się $25 \mathrm{~V}$ we wsi Osielec (pow. myślenicki) z rodziców Józefa i Anny z d. Sokołowskiej. Formację podstawową rozpoczął w Radnej (Słowenia), gdzie przeżył nowicjat, zaliczył studia filozoficzne i 8 VIII 1912 złożył śluby zakonne. Teologię studiował w Foglizzo k. Turynu, święcenia kapłańskie przyją 5 X 1919 w Przemyślu. Tam pracował jako katecheta, później był prefektem w Krakowie i w Oświęcimiu. W latach 1926-1933 był dyrektorem domu i proboszczem parafii w Kielcach. 
go i rektorem kościoła Matki Bożej Ostrobramskiej we Lwowie na Łyczakowie. Aresztowany 23 kwietnia 1940 r., spędził rok w lwowskich więzieniach. Pod koniec kwietnia 1941 r. został wywieziony na północ i po postojach w obozach nad rzekami Peczorą i Ussą znalazł się w Workucie pod biegunem północnym. Po ogłoszeniu amnestii, dopiero w lutym 1942 r. otrzymał wezwanie do wojska w Jagijulu i został kapelanem IX Dywizji w Taszlaku blisko granicy chińsko-afgańskiej. Następnie przez Morze Kaspijskie, Persję i Iran przybył do Palestyny, gdzie został mianowany kapelanem kobiet pełniących przy wojsku służbę pomocniczą. Ksiądz Guzik, idąc za głosem realizacji powołania salezjańskiego, w 1943 r. na własną prośbę został skierowany do obozu polskiej młodzieży junackiej w Nazarecie. Dodatkowo pełnił obowiązki nauczyciela III Junackiej Szkoły Mechanicznej w Kirjan-Mockin. W lipcu 1947 r. szkoły junackie ewakuowano do Anglii. Ksiądz Guzik za zgodą przełożonych, przez Wielką Brytanię, udał się do Stanów Zjednoczonych i zatrzymał się w zakładzie salezjańskim dla Polaków w Ramsey ${ }^{23}$.

\section{ZMOBILIZOWANI WE WŁOSZECH}

Z czterech salezjanów, kapelanów wojskowych zmobilizowanych w ZSSR, do Włoch przybył tylko jeden, ks. Czerniecki, i brał udział w kampanii włoskiej. II Korpus PSZ na zachodzie odczuwał duże braki związane z obsadzeniem etatów duszpasterskich. 5 czerwca 1944 r. oddziały polskie razem z aliantami wkroczyły do Rzymu. Po trzech miesiącach bp J. Gawlina zwołał polskich księży przebywających w Wiecznym Mieście na spotkanie do sióstr nazaretanek i zaproponował duchownym angaż do duszpasterstwa polowego. Przełożeni zakonni do dyspozycji władz wojskowych oddelegowali dwóch księży: Artura Słomkę i Andrzeja Świdę. Na ochotnika zgłosił się ks. Henryk Boryński, a nieco później ks. Józef Dryżałowski ${ }^{24}$.

Przez kolejne trzy lata pracował w charakterze kaznodziei w ośrodkach polonijnych w USA. Po powrocie do kraju został mianowany przełożonym domu zakonnego we Lwowie. W 1947 r. przeniósł się na stałe do USA. Zmarł 3 II 1966 w szpitalu w Suffern N. Y. Por. ASIK, t. Personalna ks. A. Guzika, karta osobowa; J. TymiŃsKi, Wspomnienie o śp. ks. A. Guziku, Ramsey 1966.

${ }^{23}$ Por. AKP, ks. S. Pietruszka do ks. A. Guzika, Jerozolima 24 VIII 1946; A. GuZIK, Ze Lwowa przez Sybir - do Palestyny, w: Historia prowincji, t. III, s. 406-407; J. Draus, Oświata i nauka, s. 156, 173; ASIW, S. PŁyWaCZYK, Zarys działalności salezjanów polskich w USA, Ramsey 1974 , mps, s. 53-54.

${ }^{24}$ AKP, Księża Kapelani Wojskowi 2. Korpusu (spis); J. PietrZYKowski, Un secolo di presenza di salesiani Polacchi fra gli emigranti, s. 168-169. 
Z tej grupy kapelanów w strefie frontowej przebywał tylko ks. A. Słomka (1906-1991 $)^{25}$. W październiku 1944 r. został on powołany w randze rotmistrza i przez dwa tygodnie był pod Faenzą. Następnie został pierwszym kapelanem odtwarzanego 25. Pułku Ułanów Wielkopolskich w Mogila (południowe Włochy). $\mathrm{Z}$ tą jednostką wojskową przebywał na zgrupowaniach w Ascoli Piceno (Marchia), Cesenie, Badrio k. Bolonii. W roku 1947 przez Neapol został ewakuowany do Wielkiej Brytanii. Był sekretarzem Kurii Biskupa Polowego Wojsk Polskich w Londynie. W marcu 1949 r. za zgodą przełożonych udał się do zakładu salezjańskiego w Ramsey w charakterze nauczyciela języka polskiego, muzyki oraz duszpasterza Polaków w USA. Do Polski wrócił w roku 1987 i zamieszkał w Warszawie. Zmarł 7 września 1991 r. i został pochowany w grobowcu salezjańskim na cmentarzu parafialnym w Czerwińsku nad Wisłą 26.

W styczniu 1940 r. legalnie do Włoch przybył ks. A. Świda (1905-1995 ${ }^{27}$ z zamiarem wyjazdu na misje. Przełożeni przeznaczyli go do szkolnictwa, ponieważ

${ }^{25}$ Urodził się 1 X w Tymbarku (pow. limanowski) z rodziców Rafała i Anny z d. Kowalówki. Nowicjat odbył w Kleczy Dolnej i 2 X 1922 złożył pierwsze śluby zakonne. Filozofię studiował w Krakowie, a teologię w WSD w Przemyślu i tam 25 VI 1933 przyjął święcenia kapłańskie. Pracował w Aleksandrowie Kujawskim, w 1936 r. przeniesiony do Warszawy. W połowie sierpnia 1939 r. przybył do Rzymu w celu przeprowadzenia kwerendy archiwalnej. Mieszkał w zakładzie Sacro Cuore w Wiecznym Mieście i od października kontynuował studia na Papieskim Uniwersytecie Gregoriańskim, które uwieńczył w 1943 r. doktoratem z historii. W Rzymie rozwinął działalność charytatywną i informacyjną wśród polskich uchodźców. Z tego powodu zagrożony aresztowaniem, przez rok 1943/1944 ukrywał się w klasztorze sióstr Klarysek w Rzymie. Por. ASIW, t. Personalna ks. A. Słomki, karta osobowa; A. SŁomkA, Wspomnienia. U salezjanów w Sacro Cuore, Ramsey 1967, mps, s. 8, 17-24; S. WiLK, Stomka Artur (1906-1991), salezjanin, kapelan, duszpasterz polonijny w USA, w: Polski Stownik Biograficzny, red. H. Markiewicz, t. 38, z. 156, Warszawa-Kraków 1997, s. 654-655.

26 A. SŁomKa, Na ziemi włoskiej, w: Udzial kapelanów wojskowych w drugiej wojnie światowej, red. J. Humeński, Warszawa 1984, s. 227-234; J. PietrZyKowski, Relacje na obczyźnie księdza Artura Stomki SDB z prymasem Polski kardynatem Augustem Hlondem w latach 1939-1945, w: Kardynat August Hlond Prymas Polski na nowo odczytany, red. W. Królikowski, G. Paprotna, Kraków 2017, s. $192-193$.

27 Urodził się 23 III w Meleczu k. Prużan na Polesiu, w rodzinie ziemiańskiej. Jego rodzicami byli Tadeusz i Julia z Zawadzkich. Uczył się w gimnazjum w Wilnie i w Bydgoszczy, studiował chemię na UJ w Krakowie i Uniwersytecie Poznańskim. Po studiach w 1929 r. wstąpił do Towarzystwa Salezjańskiego i 16 VI 1930 złożył pierwsze śluby zakonne. Filozofię studiował prywatnie podczas praktyki pedagogiczno-pastoralnej w Lądzie n. Wartą, a teologię w Krakowie; 24 VI 1937 przyją święcenia kapłańskie. Pracował w Poznaniu i w Krakowie. Po powrocie do kraju był nauczycielem w Twardogórze, proboszczem, dyrektorem i dziekanem w Lubinie Legnickim, dyrektorem Studentatu Filozoficznego w Oświęcimiu, mistrzem nowicjatu w Kopcu, inspektorem Inspektorii św. Stanisława Kostki w Łodzi, wykładowcą w Prymasowskim Studium Życia Wewnętrznego przy Metropolitalnym WSD w Warszawie. Od 1972 r. jako archiwista zamieszkał w inspektoracie w Łodzi, a od 1986 r. 
posiadał różnorodne wykształcenie: był magistrem chemii, przez trzy lata studiował w Prywatnym Instytucie Sztuk Pięknych w Poznaniu i ukończył kurs fotografii. Od roku 1940/1941 uczył w szkołach salezjańskich w Lanuvio i w Rzymie. 1 listopada 1944 r. ks. Świda został mianowany na czas wojny kapelanem wojska polskiego w stopniu kapitana. Ze względu na słaby stan zdrowia jak i warunki fizyczne był kapelanem szpitala polowego i nauczycielem żołnierzy w Komendzie Kursów Maturalnych nr 1 w bazie Korpusu. W styczniu 1945 r. skierowano go do Alessano w południowych Włoszech, gdzie przez trzy semestry przygotował trzy grupy żołnierzy i młodszych oficerów do matury. W połowie sierpnia $1946 \mathrm{r}$. razem z oficerami polskimi okrętem przypłynął do Wielkiej Brytanii. W obozie Cannon Hall uczestniczył w przygotowaniu żołnierzy do egzaminów dojrzałości. W lutym 1947 r., wobec zapowiedzianej demobilizacji II Korpusu, na wezwanie ks. inspektora J. Ślósarczyka wrócił do Polski ${ }^{28}$.

W grudniu 1939 r. legalnie z Łodzi do Rzymu przybył ks. Henryk Boryński² ${ }^{29}$ Zgłosił się do biskupa polowego Józefa Gawliny z prośbą o przyjęcie go na kapelana formującego się wojska polskiego we Francji. Wobec odmowy, oddał się do dyspozycji przełożonych zakonnych i pracował w kilku domach salezjańskich: w Palermo, koło Mediolanu i we Florencji. Latem 1944 r. został zaangażowany do duszpasterstwa polowego. Do jego zadań należała kontrola rozdzielania ofiar i darów na rzecz potrzebujących z ramienia katolickiej organizacji amerykańskiej MCWC (Marine Corps War College). W 1946 r. przybył do Anglii i był kapelanem wojskowym w obozie Mona Camp. Nie wrócił do Polski, tylko pozostał wśród powojennych emigrantów. W roku 1952 w Bradford zorganizował ośrodek duszpasterski. Nocą 13 lipca 1953 r. został telefonicznie wezwany do chorego i zginął w tajemniczych okolicznościach ${ }^{30}$.

w Warszawie. Zmarł 19 II 1995 w domu zakonnym w Warszawie i został pochowany na cmentarzu Bródnowskim im. św. Wincentego w Warszawie. Por. A. ŚwIDA, Inspektorzy polskich prowincji salezjańskich, cz. 4, Warszawa 1990, s. 26-30; J. PieTrZYKowsKi, Świda Andrzej SDB, w: Stownik biograficzny polskich archiwistów kościelnych, red. J. Marecki, t. I, Kraków 2017, s. 166-168.

${ }^{28}$ AKP, Służba wojskowa ks. A. Świdy kapelana 331/III w II Korpusie PSZ poza krajem (sprawozdanie); ASIW, t. Personalna ks. A. Świdy, Książeczka uposażenia oficera, 1 II 1945; A. ŚwIDA, Okruchy własnych wspomnień, Łódź 1985, mps, s. 46-60.

${ }^{29}$ Urodził się 8 X 1910 w Zatorze k. Krakowa, syn Jana i Anny z d. Kryńskiej. Na zakończenie nowicjatu w Czerwińsku, 24 VII 1928 złożył pierwsze śluby zakonne. Studia seminaryjne odbył w Krakowie i tam 29 V 1938 otrzymał święcenia kapłańskie. Przez rok pracował w Łodzi przy ul. Wodnej. Por. ASIW, t. Personalna ks. H. Boryńskiego, karta osobowa.

${ }^{30}$ W 1951 r. w Elenco Generale ks. Boryński został odnotowany jako „Cappelano per emigranti Polacchi”. W kazaniach demaskował polskich komunistów i prawdopodobnie przez nich został zamordowany. Policja angielska nie znalazła ciała. Por. F. BresLer, In was the cold war era of spies and traitors, „Sunday Express” 6 VI 1975, s. 8-9; Relacja ustna ks. T. Bartnika, Warszawa 8 XI 2002. 
W styczniu 1940 r. legalnie do Domu Generalnego w Turynie przyjechał ks. Józef Dryżałowski ${ }^{31}$. Otrzymał on skierowanie do miasteczka Amalia w Umbrii. Przebywała tam grupa 27 chłopców polskich utrzymywanych przez Stolicę Apostolską. Po zgłoszeniu się do duszpasterstwa polowego, 1 lutego 1945 r. został mianowany kapelanem Kursów Maturalnych nr 2 w Matino koło Alessano. Poczuł się dobrze w tym środowisku i wkrótce zorganizował chór, harcerstwo i sodalicję mariańską. W 1946 r. przez Neapol razem z żołnierzami przybył do Anglii i w Cannon Hall nadal pełnił obowiązki kapelana kursów maturalnych. Po przekształceniu II Korpusu w kadry kierownicze ks. Dryżałowski pozostał wśród byłych żołnierzy i emigrantów. W roku 1948 przybył do Huddesflield i zorganizował tam Polski Ośrodek Katolicki, zbudował dom parafialny i kościół stylizowany na gotyk nadwiślański. Tam zmarł 27 września 1968 r. i został pochowany na miejscowym cmentarzu ${ }^{32}$.

Do grona kapelanów salezjańskich na obczyźnie można jeszcze dołączyć trzech księży pracujących okresowo we Włoszech. Jednym z pierwszych był ks. Leon Kasperlik (1905-1981)33, który 27 stycznia 1940 r. z pięcioma klerykami z Oświęcimia przyjechał pociągiem do Turynu. Początkowo był nauczycielem fizyki i rysunku w Salezjańskiej Szkole Rolniczo-Misyjnej w Gumiana oraz odpowiedzialnym za wieżę meteorologiczną. W październiku 1944 r. został przeniesiony do Studentatu Filozoficznego w Foglizzo. Po kapitulacji armii niemieckiej we Włoszech razem z aliantami do Turynu przybyły formacje polskie. Polacy utworzyli Misję Wojskową w Turynie i poprosili salezjanów o przydział kapelana. Przełożony Generalny ks. Renato Ziggiotti wyznaczył do tej funkcji ks. Kasperli-

${ }^{31}$ Urodził się 14 III 1908 w Białej Podlaskiej z rodziców Władysława i Józefy z d. Kokalskiej. Nowicjat odbył w Czerwińsku i tam 24 VII 1928 złożył pierwsze śluby zakonne. Praktykę pedagogiczno-pastoralną zaliczył w Daszawie. Studia seminaryjne ukończył w Krakowie, gdzie 29 V 1938 przyjął święcenia kapłańskie. Przez rok pracował w Oświęcimiu. Por. ASIW, t. Personalna ks. J. Dryżałowskiego, karta osobowa; Elenco Generale 1929-1939.

32 ASIK, T. Korespondencja Misjonarzy, ks. J. Dryżałowski do ks. J. Ślósarczyka, Huddersfield, 29 IV 1948; Kard. A. Hlond do ks. J. Ślósarczyka, Warszawa 14 VI 1948, w: Acta Hlondiana, t. 4 , cz. 6, Ląd 1970, mps, s. 222; Pamiątka uroczystości srebrnego jubileuszu ks. Józefa Dryżałowskiego 1938-1963, Roma 1963, s. 1-5; A. ŚwIDA, Okruchy własnych wspomnień, s. 53-60; J. ŻURAwIŃSKI, Śp. ks. dziekan Józef Dryżałowski, „Gazeta Niedzielna” [Londyn] 27 X 1968; B. KanT, Salezjanie polscy na misjach, Warszawa 2005, s. 345-346.

${ }^{33}$ Urodził się 12 XI w Budapeszcie, syn Feliksa i Marianny z d. Lisieckiej. Pierwsze śluby zakonne złożył 9 VIII 1923 w Kleczy Dolnej na zakończenie nowicjatu. Podczas praktyki pedagogiczno-pastoralnej w Poznaniu (1927-1931) na Uniwersytecie Poznańskim uzyskał magisterium z fizyki. Teologię studiował w Oświęcimiu i w Krakowie, a 17 VI 1934 otrzymał święcenia kapłańskie w Poznaniu. Pracował w Studentacie Filozoficznym w Marszałkach. 7 IX 1946 specjalnym pociągiem repatriacyjnym wrócił do Polski. Zmarł 24 VII 1981 w Krakowie. Por. ASIK, t. Personalna ks. L. Kasperlika, karta osobowa. 
ka, który w niedziele i święta dojeżdżał 21 km rowerem, a wyjątkowo pociągiem z Foglizzo. Podczas wakacji mieszkał w Turynie-Valdocco, żeby mieć łatwiejszy kontakt z żołnierzami ${ }^{34}$.

Od nowego roku szkolnego 1945/1946 obowiązki kapelana żołnierzy polskich w Turynie przejął ks. Jan Grabowski (1914-1994). Dodatkowo, od stycznia 1946 r., był kapelanem ośrodków akademickich w Turynie i w Mediolanie dla 620 zdemobilizowanych oficerów uczęszczających do politechnik w tych miastach ${ }^{35}$.

Ksiądz Jan Merta (1912-2002) $)^{36}$ należał do ostatnich duszpasterzy żołnierzy polskich we Włoszech. Podobnie jak jego poprzednicy, w styczniu 1940 r. znalazł się w Piemoncie. Wykształcenie teologiczne uzupełnił w Bollengo i tam 25 czerwca 1943 r. otrzymał święcenia kapłańskie. Od roku 1945 był kapelanem przy wojsku polskim w Taranto, a następnie w Bari. Ksiądz Merta opiekował się szpitalem polowym usytuowanym w pobliskim Casa Massima. Tam za zgodą arcybiskupa Bari poświęcił nowy cmentarz dla zmarłych żołnierzy. Duszpasterz zaopatrzył sakramentami świętymi majora Henryka Sucharskiego i 31 sierpnia 1946 r. pochował na wyżej wymienionym cmentarzu dowódcę z Westerplatte. Po ewakuacji polskich oddziałów salezjanin pozostał w Bari i przez 14 lat opiekował się polskim cmentarzem wojennym ${ }^{37}$.

${ }^{34}$ Foglizzo (ze wspomnień ks. L. Kasperlika), w: Historia prowincji, t. IV, s. 482-489.

35 J. Grabowski, syn Piotra i Marianny z d. Chebdowskiej, ur. 20 II w miejscowości Lipiny w pow. kieleckim. 1 VIII 1936 złożył pierwsze śluby zakonne na zakończenie nowicjatu w Czerwińsku. W latach 1936-1938 studiował filozofię w Marszałkach, następnie został skierowany na asystencję do Krakowa. W styczniu 1940 r. wyjechał na dalszą formację seminaryjną do Piemontu. Święcenia kapłańskie przyjął 1 VII 1945 w Bollengo i pozostał 2 lata w Turynie-Valdocco do dyspozycji przełożonych. Po powrocie do Polski pracował w duszpasterstwie parafialnym. Zmarł 7 VII 1994 w Radomiu. Por. ASIK, t. Personalna ks. J. Grabowskiego, karta osobowa; Wśród byłych kombatantów (ks. Jan Grabowski), w: Historia prowincji, t. III, s. 355-357; S. KosıńsKI, Działalność polskich salezjanów na emigracji w latach 1893-1975, w: Idąc tedy nauczajcie. Sto lat misji salezjańskich, red. S. Pruś, Kraków-Łódź 1976, s. 112.

${ }^{36}$ Urodził się 6 V w Górze Włodowskiej k. Zawiercia, syn Piotra i Anny z d. Mucha. Nowicjat odbył w Czerwińsku i na jego zakończenie 26 VII 1934 złożył pierwsze śluby zakonne. W latach 1935-1937 w Marszałkach studiował filozofię i uzupełniał wykształcenie średnie. Przez kolejne 2 lata był w Oświęcimiu na praktyce pedagogiczno-duszpasterskiej. Po święceniach początkowo pracował w Bagnolo, gdzie od 1942 r. tymczasowo mieścił się prowadzony przez Towarzystwo Salezjańskie Papieski Wydział Teologiczny i Wyższy Instytut Pedagogii. W 1968 r. wrócił do Polski i należał do domu zakonnego w Przemyślu. Został awansowany do stopnia pułkownika. Zmarł 23 II 2002 w Przemyślu. Por. ASIK, t. Personalna ks. J. Merty; J. GAJDA, Ks. kapelan płk Jan Merta SDB we wspomnieniach, „Nasza Przeszłość” 2015, t. 123, s. 268-269.

37 „Dziennik Bałtycki” 1971, nr 198; M. WIRTH, Da don Bosco ai nostri giorni. Tra storia e nuove sfide, Roma 2000, s. 333; J. PiEtrzyкowski, Salezjanie w Polsce 1945-1989, Warszawa 2007, s. 389. 


\section{ZAKOŃCZENIE}

Towarzystwo Salezjańskie jako międzynarodowe zgromadzenie zakonne posiada swoje placówki szkolno-wychowawcze i duszpasterskie w prawie wszystkich krajach europejskich. Członkami tych wspólnot byli także Polacy, którzy interesowali się losem rodaków przebywających poza krajem i w różny sposób nieśli im pomoc charytatywną, oświatową, informacyjną, dobroczynną. Znaczącym wyrazem postawy patriotycznej salezjanów polskich był ich udział w duszpasterstwie polowym poza granicami Ojczyzny. W niniejszym opracowaniu świadomie pominięto księży z byłych obozów koncentracyjnych na terenie III Rzeszy, którzy po zakończeniu działań wojennych byli kapelanami w polskich obozach DP (Displasced Persons) dla osób przemieszczających się.

\section{BIBLIOGRAFIA}

\section{Źródła}

Archiwum Katedry Polowej Wojska Polskiego w Warszawie [AKP]

T. Depesza szyfr tajne

T. Księża kapelani wojskowi

T. Księża pracujący aktualnie wśród rodzin wojskowych

Archivio Salesiano Centrale [ASC]

Sygn. E 999 Polonia Generica

Sygn. F 000, Salesiani durante l'ocupazione

Archiwum Salezjańskie Inspektorii Krakowskiej [ASIK]

Sygn. 1546 ks. Adam Cieślar, Kronika 1940

T. Personalna ks. Józefa Czernieckiego

T. Personalna ks. Leona Czerwińskiego

T. Personalna ks. Ignacego Dobiasza

T. Personalna ks. Alojzego Golubskiego

T. Personalna ks. Jana Grabowskiego

T. Personalna ks. Antoniego Guzika

T. Personalna ks. Leopolda Kasperlika

T. Personalna ks. Erazma Malczyka

T. Personalna ks. Jana Symiora

Sygn. 1687 T. Wspomnienia.

Archiwum Salezjańskie Inspektorii Warszawskiej [ASIW]

T. Byłe Placówki, Łódź św. Jerzy

T. Personalna ks. Józefa Dryżałowskiego 
T. Personalna ks. Jana Kapusty

T. Personalna ks. Artura Słomki

T. Personalna ks. Andrzeja Świdy

T. Personalna ks. Franciszka Tomasika

Elenco Generale della Societá di S. Francesco di Sales 1928-1952, Torino 1928-1952.

\section{Zbiory prywatne}

Acta Hlondiana. Materiały do życia i działalności kardynała Augusta Hlonda, prymasa Polski 1881-1948, zebrał ks. S. Kosiński, t. 4, Ląd 1970-1971 (mps).

\section{Opracowania}

BRESLER F., In was the cold war era of spies and traitors, „Sunday Express” 6 VI 1975, S. 8-9.

Ciechalski A., ZıóŁkowski B., Antonowicz Ignacy Tadeusz (SDB) (1980-1941), salezjanin, kapelan Armii Polskiej gen. J. Hallera, profesor teologii, dyr. salezjańskich zakładów naukowych, męczennik z Auschwitz, kandydat na ołtarze, w: Kazimierz Wielki oraz niepospolici z Kowala i okolic. Słownik biograficzny. Kalendarium, red. Z.J. Zasada, B. Ziółkowski, Włocławek-Kowal: Lega 2006, s. 36-37.

Draus J., Oświata i nauka polska na Bliskim Wschodzie 1939-1950, Lublin: TN KUL 1983.

DzWONKowski R., Leksykon polskiego duchowieństwa represjonowanego w ZSRS 19391988, Lublin: TN KUL 2003.

GAJDA J., Ks. kapelan płk Jan Merta SDB we wspomnieniach, „Nasza Przeszłość” 2015, t. 123 , s. 265-277.

GRZYB J., Wspomnienie pośmiertne, Lublin 1998 (mps).

Historia prowincji św. Jacka Towarzystwa Salezjańskiego w Polsce. Z lat wojennych 19391945, red. J. Ślósarczyk, t. III-IV, Pogrzebień 1966 (mps).

Isfahan miasto polskich dzieci, red. I. Beaupré-Stankiewicz [i in.], Londyn 1988.

KAMIŃSKI F., Moja droga do kapłaństwa, Warszawa: Wydawnictwo Nowy Świat 2004.

KANT B., Księga męczeństwa salezjanów polskich, Warszawa: Wydawnictwo Salezjańskie 2012.

Kant B., Salezjanie polscy na misjach, Warszawa: Wydawnictwo Salezjańskie 2005.

KANTAK K., Dzieje uchodźstwa polskiego w Libanie 1943-1950, Bejrut: Cedr i Orzeł 1955.

Knothe J., Niedaleko Damaszku, Warszawa: Iskry 1961.

KosıŃSKI S., Działalność polskich salezjanów na emigracji w latach 1893-1975, w: Idąc tedy nauczajcie. Sto lat misji salezjańskich, red. S. Pruś, Kraków-Lódź: Towarzystwo Salezjańskie 1976, s. 102-120.

KraHEL T., Martyrologium duchowieństwa archidiecezji wileńskiej 1939-1945, Białystok: Wydawnictwo BUK 2017.

Nabywaniec S., Posługa duszpasterska na frontach I wojny światowej, „Resovia Sacra” 23(2016), s. 213-228.

Nekrolog salezjanów polskich 1891-1976, Kraków-Lódź: Towarzystwo Salezjańskie 1976 (mps). 
Ostoja-MitkiEwicz M., „Wojna jest grzechem”. Przykłady braterstwa polsko-węgierskiego w okresie II wojny światowej, Warszawa: Neriton 2001.

Pamiątka uroczystości srebrnego jubileuszu ks. Józefa Dryżałowskiego 1938-1963, Roma 1963.

PIETRZYKowSKi J., Relacje na obczyźnie księdza Artura Słomki SDB z prymasem Polski kardynałem Augustem Hlondem w latach 1939-1945, w: Kardynał August Hlond Prymas Polski na nowo odczytany, red. W. Królikowski, G. Paprotna, Kraków: Wydawnictwo Naukowe Akademii Ignatianum w Krakowie 2017, s. 187-207.

PietrZykowski J., Salezjanie w Polsce 1945-1989, Warszawa: Wydawnictwo Salezjańskie 2007.

PietrZykowski J., Symior Jan (1879-1959), salezjanin, rektor Polskiej Misji Katolickiej w Londynie, w: Polski Słownik Biograficzny, red. B. Swolkień, J. Syska, t. 46, z. 189, Warszawa: Zakład Narodowy im. Ossolińskich - Wydawnictwo PAN 2009, s. 239.

PietrzYKowski J., Świda Andrzej SDB, w: Słownik biograficzny polskich archiwistów kościelnych, red. J. Marecki, t. I, Kraków: Wydawnictwo Unum 2017, s. 166-168.

PietrzyKowski J., Un secolo di presenza di salesiani Polacchi fra gli emigranti. Cenni storici, „Ricerche Storiche Salesiane” 1999, nr 1(34), s. 163-173.

PietrzyKowski J., Zasłużeni dla Aleksandrowa Kujawskiego, w: Salezjanie w Aleksandrowie Kujawskim 1919-2009. Studia i materiały źródłowe, red. J. Wąsowicz, Piła: Wydawnictwo Salezjańskie 2009, s. 89-101.

Rodzina salezjańska w Polsce. Wykaz domów i osób, red. L. Kaliński, Warszawa: Wydawnictwo Salezjańskie 1988.

SŁomka A., Na włoskiej ziemi, w: Udział kapelanów wojskowych w drugiej wojnie światowej, red. J. Humeński, Warszawa: ATK 1984, s. 209-234.

SŁomka A., Wspomnienia. U salezjanów w Sacro Cuore, Ramsey 1967 (mps).

SzCZYGIELSKi R., Działalność salezjanów polskich na rzecz emigracji londyńskiej 18941967, Lublin 2001 (mps, Biblioteka WSD w Lądzie nad Wartą).

ŚwIDA A., Inspektorzy polskich prowincji salezjańskich, cz. 4, Warszawa: Salezjański Ośrodek Misyjny 1990.

ŚwIDA A., Okruchy własnych wspomnień, Łódź 1985 (mps).

WiLK S., Słomka Artur (1906-1991), salezjanin, kapelan, duszpasterz polonijny w USA, w: Polski Słownik Biograficzny, red. H. Markiewicz, t. 38, z. 156, Warszawa-Kraków: Zakład Narodowy im. Ossolińskich - Wydawnictwo PAN 1997, s. 654-655.

WirTh M., Da Don Bosco ai nostri giorni. Tra storia e nuove sfide, Roma: LAS 2000.

Wykaz Placówek i Współbraci Polskich Prowincji Towarzystwa Salezjańskiego 19781989, Kraków-Lódź (mała poligrafia).

ŻURAwIŃsKi J., Śp. ks. dziekan Józef Dryżałowski, „Gazeta Niedzielna” [Londyn] 27 X 1968.

ŻUREK W., ,Jeńcy na wolności”. Salezjanie na terenach byłego ZSSR po II wojnie światowej, Kraków: Poligrafia Salezjańska 1998. 


\section{SALEZJANIE POLSCY - KAPELANI WOJSKOWI I DUSZPASTERZE NA OBCZYŹNIE}

\section{Streszczenie}

Salezjanie polscy duszpasterstwo polowe traktowali jako sezonową działalność dobroczynną świadczoną bliźnim. W zdecydowanej większości była to inicjatywa oddolna poszczególnych księży, którą tolerowali przełożeni zakonni. Podczas pierwszej wojny światowej praca salezjanów przebywających w Europie Zachodniej ograniczała się zasadniczo do opieki nad rodakami przebywającymi w obozach jenieckich czy szpitalach. W czasie drugiej wojny światowej księża poza krajem byli już na etatach kapelanów wojskowych zarówno wśród internowanych Polaków na Węgrzech, jak i na bojowym i tułaczym szlaku od Związku Sowieckiego, poprzez Włochy, do Wielkiej Brytanii. Większość z tych księży pozostała wśród żołnierzy kombatantów: w Anglii i w Stanach Zjednoczonych.

Słowa kluczowe: salezjanie; kapelani wojskowi; emigracja

\section{POLISH SALESIANS - MILITARY CHAPLAINS AND PRIESTS IN FOREIGN LANDS}

\section{Sum mary}

Polish Salesians regarded field priesthood as a seasonal charitable activity performed for the sake of neighbours. It was mostly a rank-and-file initiative of particular priests, which was tolerated by monastic superiors. During the First World War the work of the Salesians staying in Western Europe basically consisted in taking care of their compatriots in POW's camps or hospitals. During the Second World War the priests staying away from Poland already worked as army chaplains both among the interned Polish people in Hungary and on a wandering and combat trail leading from the Soviet Union through Italy to Great Britain. Most of those priests stayed among combatant soldiers in England or the United States.

Keywords: Salesians; army chaplains; emigration 